to these belonged Carpenter. He derived great pleasure from his gramophones ingeniously arranged to play both sides of a record consecutively without a break: the opera and concerts were his one relaxation and the only accepted reasons for his going out in the evening. His library was peculiar in more than one respect. He took great pride in the workmanship and binding of his books and regretted the decline in that craft. His tastes would be called oldfashioned : literature of the French sentimentalists and George Moore were among his favourites. $\mathrm{He}$ detested anything shoddy or imperfect.

This attitude is reflected in Dr. Carpenter's annual addresses as chairman, which instead of the usual platitudes contained studied discourses on matters of moment to the policy of the company, in which the meaning of every word had been weighed : an immense amount of time and trouble went to the preparation of these.

How shall we reconcile the dual charaeters; the shy sentimental music-loving artist with an intense sense of perfection and a hatred of shams; the reasoning intrepid engineer seeking to put into his creative work the artistic expression which he could not by his own hand achieve with pen or pianothe great leader setting so high a standard for him. self that he felt he could not trust to others to execute his plans and so becoming lonely, unable to depute in the way that moderm industry demands, carrying most of his burdens himself and in later years almost unwilling to be helped.

Each one of us is the integration of our many component parts, and who shall judge if the result is short of the ideal. Charles Carpenter was a great engineer, a cornerstone of the gas industry to which he devoted his life, the best of masters to his thousands of work-people, to whom more than anything else he brought fair dealing and security, and a complex and lovable personality to his intimates. We shall think of him at his best and remember how in life he did

"Strive and hold cheap the strain;

Learn, nor account the pang;

Dare, never grudge the throe.'

E. F. A.

\section{Prof. W. H. Merrett}

Prof. W. H. Merrett, formerly assistant-professor of metallurgy at the Royal School of Mines, who retired from his post rather more than a year ago, died after a short illness on October 29 last. He was sixty-six years of age. A fortnight before his retirement he had a severe stroke from which he never really recovered. It was followed by another, after an interval of little more than a year, which proved fatal.

Merrett received his school education at St. Olave's School, London, during which time he gained a number of valuable prizes for science, and obtained a Royal Exhibition of the Board of Education. In 1891 he entered the Royal School of Mines, and after spending three years there was awarded a first-class in the associateship of the School in metallurgy. This was during the tenure of the late Sir William Roberts-Austen of the professorship of metallurgy. In addition to holding this post, Sir William was chemist and assayer of the Mint, and it was there that he carried out his researches on metals and alloys. Thither Merrett proceeded after graduation and acted as an assistant in the prosecution of these researches during the next seven years. It was a particularly interesting period in the development of that branch of metallurgy which is to-day known as metallography. These were the early days of the subject and the foundations were still being laid. Roberts-Austen was himself one of the pioneers; he was a member of the Alloys Research Committee of the Institution of Mechanical Engineers and published five reports of experimental work in all. It is with the work for the fifth report that Merrett was particularly associated, acting as an assistant to Roberts-Austen and Stansfield.

The method of investigating the thermal inversions of metals and alloys at that time by taking cooling and heating curves was due to the late M. Osmond, using the thermo-electric pyrometer introduced by the late H. le Chatelier. In this method the coordinates were time and temperature and, while it was quite satisfactory in the upper ranges of tem. perature, it was not so suitable for the lower ranges where the rate of cooling becomes very slow. RobertsAusten and Stansfield accordingly devised the 'differential' method, in which a neutral body was also present. (Strictly speaking it is not a differential but a difference method, since no differential coefficient is involved.) In this method temperature and difference of temperature were the co-ordinates, and accordingly the rate of cooling did not matter. Moreover, accidental fluctuations in the rate of cooling of the furnace were cancelled out. This method could be made very sensitive, and by its means accurate thermal curves of iron and carbon steels were obtained. In the Fifth Alloys Report is published a curve of a sample of electro-deposited iron which had cooled from $1150^{\circ}$ to $100^{\circ} \mathrm{C}$. It represented the most skilled piece of experimental work in this field at that time. In addition, this research contains a number of photomicrographs of steel structures of great clearness. Merrett developed a skilful technique in both these branches of metallography, which contributed very much to the value of the report in question. He was the first to apply the electric arc light as a method of illumination in the metallographic microscope. The Sixth Report to the Alloys Research Committee had been begun during Roberts-Austen's lifetime but owing to his illness and death it was completed by the late Prof. Gowland with the assistance of Merrett. This deals with the heat treatment of steel.

Roberts-Austen was also a member of a War Office and Admiralty Committee on Explosives and Ordnance. In this capacity he carried out a number of investigations, most of which were of a strictly confidential nature. These comprised $(a)$ the nature of erosion in gun tubes, $(b)$ the effects of various additions of nickel, ehromium, tungsten and 
manganese on the mechanical properties of gun steels, and (c) the effects of heat treatment on gun steels. Merrett carried out all the experimental work on which these reports were based. He conducted an investigation, also under Roberts-Austen, for the Board of Trade on the St. Neots railway disaster. This examination was published in extenso as a Blue Book in 1900, and the accident traced to a broken rail. He found evidence of a 'martensitic' structure, which is associated with great brittleness, on its surface. A temperature of at least $800^{\circ} \mathrm{C}$. is required to produce this. Merrett was at least partly, if not wholly, responsible for a new lyddite shell exploder, for which a secret patent was taken out by the late Lord Haldane. He was also largely concerned with the development of ammonium nitrate for use as an ingredient of explosives, which led to the introduction of amatol.

In 1901, Merrett was appointed instructor in the Metallurgy Department of the Royal School of Mines, and spent the remainder of his professional life there until his retirement. $\mathrm{He}$ rose to the position of assistant professor. He was an admirable teacher, clear and inspiring. This side of his work appealed to him very much. He was always anxious that his students should conduct themselves with credit in their examinations, and this led him sometimes to take a kindlier view of their performances than the results warranted. As early as the age of sixteen years he showed his taste for military work and joined the Srd Middlesex Artillery in 1888. He was transferred as a sapper ten years later to the newlyformed Corps of London Electrical Engineers. He rose to the rank of major and was mobilized for active service on July 29, 1914. During the Great War he was in charge of various coast defences and anti-aircraft units. Afterwards his scientific knowledge was made available to tho Ordnance College as instructor in metallurgy, chemistry and explosives. In 1926 he retired from military service on reaching the age limit and was awarded the Territorial Decoration and Long-Service Medal.

Merrett was a member of many scientific societies, a governor of the School of Metalliferous Mining at Camborne and a member of council of the Institution of Mining and Metallurgy. The writer was a colleague of his at the Royal School of Mines for twenty-three years. He possessed qualities which made him one of the most delightful of fellow workers. Some of these, such as punctuality and reliability, could probably be traced to some extent to his military training. Others, such as his perfect courtesy, generosity and good temper, were natural to him. It is impossible to think that he had an enemy. His many friends mourn the loss of one of the kindest and most unselfish of men.

H. C. H. C.

WE regret to announce the following deaths:

Mr. J. F. Bailey, director of the Botanic Gardens, Brisbane, from 1905 until 1917, and director of the Botanic Garden, Adelaide, from 1917 until 1932.

Prof. E. M. East, professor of genetics in Harvard University, aged fifty-nine years.

Admiral Sir Herbert Purey-Cust, K.B.E., C.B., formerly hydrographer to the Navy, on November 11, aged eighty-one years.

\section{News and Views}

\section{The Royal Society}

His Majesty the KING has been graciously pleased to approve the recommendations made by the Council of the Royal Society for the award of the two Royal Medals for the current year to Dr. F. W. Aston, F.R.S., in recognition of his discovery of the isotopes of non-radioactive elements; and to Prof. R. A. Fisher, F.R.S., in recognition of his important contributions to the theory and practice of statistical methods. The Council of the Royal Society at its recent meeting recommended the following for election as officers and council at the anniversary meeting on November 30: President, Sir William Bragg; Treasurer, Sir Henry Lyons; Secretaries, Prof. A. V. Hill and Prof. A. C. G. Egerton; Foreign Secretary, Sir Albert Seward; Other members of the Council, Prof. F. C. Bartlett, Prof. F. E. Fritsch, Prof. M. Greenwood, Mr. H. L. Guy, Sir Thomas Holland, Dr. A. D. Imms, Prof. C. K. Ingold, Prof. G. B. Jeffery, Prof. J. Mellanby, Prof. J. Proudman, Dr. F. L. Pyman, Prof. O. W. Richardson, Prof. W. W. C. Topley, Prof. D. M. S. Watson, Prof. R. Whiddington, Prof. R. Whytlaw-Gray.

\section{Prof. Enrico Fermi}

The Nobel Prize for Physics for 1938 has been awarded to Prof. E. Fermi, professor of theoretical physics in the University of Rome, and his work in connexion with artificial radioactivity induced by neutrons is specially mentioned in the award. Bombardment of the nucleus with neutrons is peculiarly effective in producing nuclear reactions because the neutron does not experience the strong electrostatic forces which oppose the approach of a proton or $\alpha$-particle. Fermi in 1934 showed that most nuclei, even the heaviest which are most resistant to charged particles, are disrupted by neutrons with the formation of new radioactive nuclei. In the same year, he discovered that the effectiveness of neutron bombardment is greatly increased in the presence of masses of water or paraffin, and concluded that the neutrons are slowed down by collisions with hydrogen nuclei in these substances, and that the slow neutrons have a high probability of entering and disrupting nuclei. Prof. Fermi has, however, made other outstanding contributions to atomic physics. In 1926 he applied Pauli's exclusion principle to deduce a 